\title{
A Detailed Study of Antimicrobial Sensitivity Pattern of Penton Valentine Leucocidin Gene Positive and Negative Staphylococcus aureus from Pus Samples
}

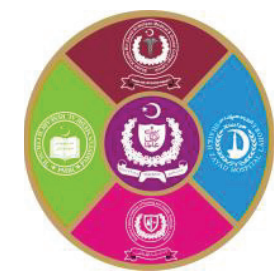

Asma Akram, ${ }^{2}$ Mateen Izhar, ${ }^{2}$ Anwaar Basheer, ${ }^{1}$ Mariya Ali, ${ }^{3}$ Asma Yaqoob, ${ }^{4}$ Asim Saifullah

${ }^{1}$ Department of Pathology, Continental Medical College, Lahore

${ }^{2}$ Department of Microbiology, Shaikh Zayed Medical Complex, Lahore

${ }^{3}$ Department of Pathology, Fatima Memorial Medical and Dental College, Lahore

${ }^{4}$ Department of Pediatric Orthopedic Surgery, Children Hospital, Lahore

\begin{abstract}
Introduction: Staphylococcus aureus harboring Panton Valentine Leucocidin gene are emerging and spreading worldwide. PVL gene was first identified by Noel Panton and Francis Valentine in 1932 who IC Pakistan only limited data is available regarding the effect of PVL gene on sensitivity pattern of Staphylococcus aureus. Therefore, this study was conducted to understand the antimicrobial sensitivity pattern of both PVL positive and negative Staphylococcus aureus isolates. Aims \& Objectives: This study was conducted to understand the antimicrobial sensitivity pattern of both PVL positive and PVL negative Staphylococcus aureus isolated from pus samples received from various indoor and outdoor departments of a tertiary care hospital of Lahore. Place and duration of study: Microbiology and Molecular Biology Laboratory Shaikh Zayed Hospital Lahore. Duration of study is one year after the approval of research topic. Material \& Methods: A total of 384 Staphylococcus aureus isolates from skin and soft tissue infections were identified and selected. Their antimicrobial sensitivity testing was done by Kirby disc diffusion method using Muller Hinton agar. Results: Frequencies of PVL gene in MRSA and MSSA were 51\% and 44\% respectively. Frequency of PVL gene was also found to be high in Ciprofloxacin sensitive, Gentamicin sensitive, Erythromycin resistant and fusidic acid resistant isolates. Conclusion: Almost half of Staphylococcus aureus isolates were found PVL positive. They were mostly multidrug resistant. The PVL positive Staphylococcus aureus isolates showed high resistance against antibiotics than PVL negative isolates.
\end{abstract}

ABSTRACT

Key words: PVL (Panton Valentine Leucocidin), MRSA (Methicillin Resistant Staphylococcus aureus)

\section{INTRODUCTION}

In species included till date. Staphylococcus aureus is one of the most critical and harmful pathogen among these Staphylococci. ${ }^{1}$ It is the most widely recognized microbe that causes skin and soft tissue diseases in both children and adults. ${ }^{3}$ Staphylococcus aureus also cause life-threatening infections, for example, hemorrhagic pneumonia and endocarditis. ${ }^{4}$ Staphylococcus aureus colonize different body sites however nasal pit is the main site of colonization. Pathogenic factors produced by Staphylococcus aureus render this organism exceedingly pathogenic. ${ }^{5}$ They include surface proteins, toxins and enzymes. ${ }^{6}$ In the past, Staphylococcus aureus caused high mortality due to its pathogenicity. This mortality was reduced to sufficiently low levels due to discovery of Penicillin in 1940s. But relieve from Penicillin was brief as Penicillin resistant Staphylococcus aureus (PRSA) emerged rapidly. Methicillin, a beta lactamaseinsensitive beta-lactam prepared in late 1950s was a good alternative to PRSA but Methicillin resistant Staphylococcus aureus that were resistant to commonly available beta lactamase from hospital settings. It caused an increased use of antibiotic of last resort vancomycin as a treatment option for MRSA. Initially, the rates of MRSA increased slowly and they were mostly isolated from hospital settings but later dramatic increase in frequency of MRSA occurred ${ }^{2}$ and it was followed by isolation of MRSA from community settings from the people that were previously healthy and had no or very little chance of carrying MRSA. ${ }^{7}$ Community acquired Staphylococcus aureus infection was previously caused by Methicillin sensitive 
Staphylococcus aureus. ${ }^{8}$ It was also observed that in many areas of world CA-MRSA had become more common than CA-MSSA. ${ }^{9}$ Moreover, CA-MRSA is more infectious than HA-MRSA. The clinical picture of HA-MRSA infection is less severe than CA-MRSA but it is difficult to treat as compared to CA-MRSA. ${ }^{2}$ Methicillin resistance in Staphylococcus aureus is mediated by acquiring $m e c A$ gene that encodes altered penicillin binding protein that has low affinity for beta lactams. Both MRSA and MSSA can carry PVL gene (Panton Valentine Leucocidin gene) which makes them more aggressive and pathogenic. It was discovered by Van deVelde in 1894 who found its capability of lysing leucocytes and is named after Sir Philip Noel Panton and Francis Valentine who related it with skin and soft tissue diseases in $1932 .{ }^{5}$ PVL gene is acquired by Staphylococcus aureus by viruses called Prophages which carry various genes between bacteria. ${ }^{10}$ These toxins destroy the outer membranes of white blood cells by the combine action of 2 secretory proteins named $\mathrm{S}$ and $\mathrm{F}$ by making pores in the membranes of cell and causing leakage of cellular contents through that pores resulting in cell death. ${ }^{11}$ Purified PVL is only toxic to white blood cells and macrophages in humans and rabbits, they are not toxic for erythrocytes. ${ }^{12}$ In Nepal a study was carried out in 2014 with sample size of 73 including MRSA and MSSA and they were isolated from various samples; among them PVL gene was $26.1 \%$ in MRSA and $51.9 \%$ in MSSA. ${ }^{13}$ While in India a study was conducted in which overall prevalence of PVL was $62.85 \%$ and among MRSA and MSSA it was $85.1 \%$ and $48.8 \%$ respectively. ${ }^{14}$ Limited work has been done on PVL gene and effect of harboring gene on organism's sensitivity pattern in Pakistan. So, this study was planned to observe the drug resistance pattern of PVL positive and PVL negative Staphylococcus aureus collected both from indoor and outdoor.

\section{Abbreviations:}

CA-MRSA: Community Acquired Methicillin Resistant Staphylococcus aureus; CLSI: Clinical and Laboratory Standards Institute; HA-MRSA: Hospital Acquired Methicillin Resistant Staphylococcus aureus; MDR: Multidrug Resistant; PCR: Polymerase Chain Reaction; PVL: Panton Valentine Leukocidin;

\section{MATERIAL AND METHODS}

\section{Approval and consent to participate}

Ethical approval to conduct the study was obtained from the Institutional Review Board (IRB), Federal
Postgraduate Medical Institute, Shaikh Zayed Hospital, and Lahore.

\section{Collection and Sample Processing}

Pus samples from various indoor and outdoor departments of Shaikh Zayed Hospital Lahore were collected. Data related to samples was noted on standardized Proforma.

Samples were processed and Staphylococcus aureus was identified according to Laboratory SOPs. Antibiotic susceptibility testing was performed according to CSLI guidelines edition 2016. Following drugs were used; Cefoxitin, Erythromycin, Ciprofloxacin, Gentamycin, Fusidic acid, Penicillin, Vancomycin and Linezolid. Staphylococcus aureus showed resistance to at least three antimicrobial drugs were categorized as multidrug resistant.

\section{RESULTS}

Table-1 shows $72 \%$ resistant in Staphylococcus aureus while PVL gene frequency was high in Ciprofloxacin sensitive cases but relationship between drug sensitivity and PVL gene is not significant $(\mathrm{p}=0.246)$. While Table-2. Shows $63 \%$ resistant in Staphylococcus aureus against Erythromycin while PVL gene frequency was high in resistant cases. Table-3 shows high sensitivity against Gentamycin while PVL gene frequency was high in sensitive cases. Table-4 shows high sensitivity against Fusidic acid and PVL gene frequency is also high in sensitive cases. Table-5 and Fig-1 describe that mostly isolates were multidrug resistant and PVL gene frequency was also high in MDR cases while Table- 6 and Fig-2 explain that most of Staphylococcus aureus were MRSA and half of those MRSA were PVL positive.

\begin{tabular}{|l|c|c|c|c|}
\hline Ciprofloxacin & $\begin{array}{c}\text { Total } \\
\mathbf{n = 3 8 4}\end{array}$ & PVL+ve & PVL-ve & $\begin{array}{c}\text { p } \\
\text { value }\end{array}$ \\
\cline { 1 - 4 } Sensitive & $92(24 \%)$ & $50(54.3 \%)$ & $42(45.65 \%)$ & \multirow{2}{*}{0.246} \\
\cline { 1 - 2 } & $15(3.9 \%)$ & $5(33.3 \%)$ & $10(66.6 \%)$ & \\
\cline { 1 - 3 } Resistant & $277(72.1 \%)$ & $131(47.2 \%)$ & $146(52.7 \%)$ & \\
\cline { 1 - 3 } & &
\end{tabular}

Table-1: Penton Valentine Leukocidin gene and Ciprofloxacin

\begin{tabular}{|l|c|c|c|c|}
\hline Erythromycin & $\begin{array}{c}\text { Total Staph } \\
\text { aureus n=384 }\end{array}$ & PVL+ve & PVL-ve & p value \\
\hline Sensitive & $\begin{array}{c}130 \\
(33.9 \%)\end{array}$ & $\begin{array}{c}61 \\
(47 \%)\end{array}$ & $\begin{array}{c}69 \\
(53 \%)\end{array}$ & \\
\cline { 1 - 3 } Intermediate & $\begin{array}{c}11 \\
(2.9 \%)\end{array}$ & $\begin{array}{c}4 \\
(36.36 \%)\end{array}$ & $\begin{array}{c}7 \\
(63.6 \%)\end{array}$ & \multirow{2}{*}{0.625} \\
\cline { 1 - 3 } Resistant & $\begin{array}{c}243 \\
(63 \%)\end{array}$ & $\begin{array}{c}121 \\
(49 \%)\end{array}$ & $\begin{array}{c}122 \\
(51 \%)\end{array}$ & \\
\cline { 1 - 3 } & $(63 \%)$ & &
\end{tabular}

Table-2: Erythromycin and PVL gene relation 


\begin{tabular}{|l|c|c|c|l|}
\hline Gentamycin & $\begin{array}{c}\text { Total } \\
\mathbf{n = 3 8 4}\end{array}$ & PVL+ve & PVL-ve & p value \\
\cline { 1 - 4 } Sensitive & $\begin{array}{c}235 \\
(61.2 \%)\end{array}$ & $\begin{array}{c}120 \\
(51 \%)\end{array}$ & $\begin{array}{c}115 \\
(49 \%)\end{array}$ & \\
\cline { 1 - 4 } Intermediate & $\begin{array}{c}2 \\
(0.5 \%)\end{array}$ & $\begin{array}{c}1 \\
(50 \%)\end{array}$ & $\begin{array}{c}1 \\
(50 \%)\end{array}$ & \multirow{2}{*}{0.428} \\
\cline { 1 - 3 } Resistant & $\begin{array}{c}147 \\
(38.3 \%)\end{array}$ & $\begin{array}{c}65 \\
(44.3 \%)\end{array}$ & $\begin{array}{c}82 \\
(56 \%)\end{array}$ & \\
\cline { 1 - 3 } & & &
\end{tabular}

Table-3: Penton Valentine Leukocidin gene and Gentamycin

\begin{tabular}{|l|c|c|c|c|}
\hline Fusidic Acid & $\begin{array}{c}\text { TotalStaph } \\
\text { aureus } \mathbf{n = 3 8 4}\end{array}$ & PVL+ve & PVL-ve & p value \\
\hline Sensitive & $\begin{array}{c}240 \\
(62.5 \%)\end{array}$ & $\begin{array}{c}120 \\
(50 \%)\end{array}$ & $\begin{array}{c}120 \\
(50 \%)\end{array}$ & \multirow{2}{*}{0.429} \\
\hline Resistant & $\begin{array}{c}144 \\
(37.5 \%)\end{array}$ & $\begin{array}{c}66 \\
(46 \%)\end{array}$ & $\begin{array}{c}78 \\
(54 \%)\end{array}$ & \\
\hline
\end{tabular}

Table-4: Panton Valentine Leucocidin gene and Fusidic acid

\begin{tabular}{|l|c|c|c|c|}
\hline $\begin{array}{c}\text { Drug } \\
\text { resistance }\end{array}$ & $\begin{array}{c}\text { Total Staph } \\
\text { aureus } \text { n=384 }\end{array}$ & PVL+ve & PVL-ve & $\begin{array}{c}\text { p } \\
\text { value }\end{array}$ \\
\hline MDR & $\begin{array}{c}290 \\
(75.5 \%)\end{array}$ & $\begin{array}{c}143 \\
(49.3 \%)\end{array}$ & $\begin{array}{c}147 \\
(50.7 \%)\end{array}$ & \\
\cline { 1 - 3 } Non-MDR & $\begin{array}{c}94 \\
(24.5 \%)\end{array}$ & $\begin{array}{c}43 \\
(46 \%)\end{array}$ & $\begin{array}{c}51 \\
(54 \%)\end{array}$ & \\
\cline { 1 - 3 } & & &
\end{tabular}

Table-5: Relationship of MDR and PVL gene

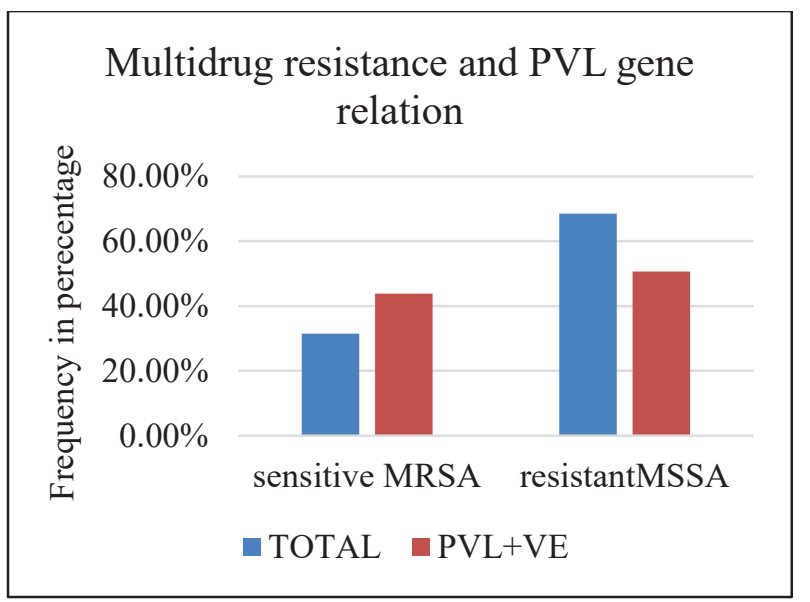

Fig-1: Relation between MDR and PVL gene

\begin{tabular}{|c|c|c|c|c|}
\hline Methicillin & Total & PVL+ve & PVL-ve & $\begin{array}{c}\mathbf{p} \\
\text { value }\end{array}$ \\
\hline $\begin{array}{l}\text { Sensitive } \\
\text { MSSA }\end{array}$ & $\begin{array}{c}121 \\
(31.5 \%)\end{array}$ & $\begin{array}{c}53 \\
(43.8 \%)\end{array}$ & $\begin{array}{c}68 \\
(56.2 \%)\end{array}$ & \multirow{2}{*}{0.228} \\
\hline $\begin{array}{l}\text { Resistant } \\
\text { MRSA }\end{array}$ & $\begin{array}{c}263 \\
(68.5 \%) \\
\end{array}$ & $\begin{array}{c}133 \\
(50.6 \%)\end{array}$ & $\begin{array}{c}130 \\
(49.4 \%)\end{array}$ & \\
\hline
\end{tabular}

Table-6: Relationship between Methicillin sensitivity and PVL gene

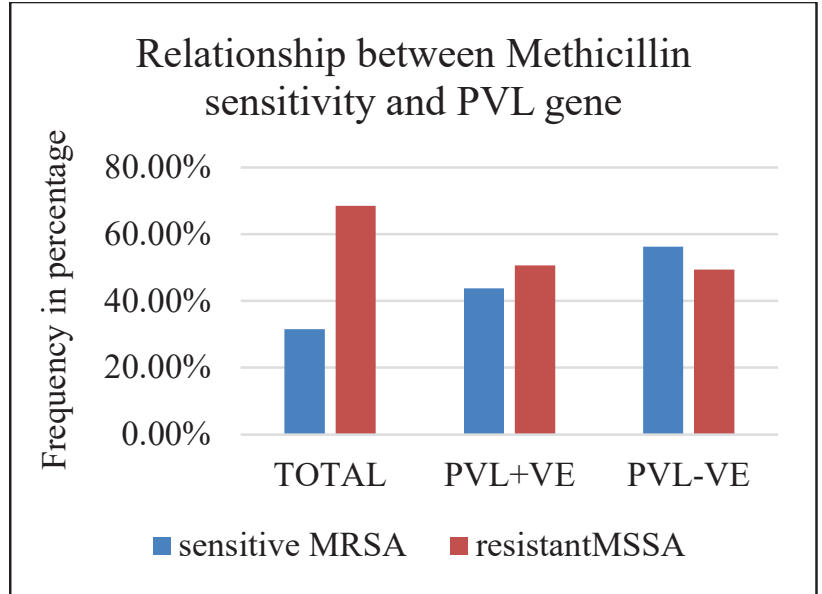

Fig-2: Relation between Methicillin sensitivity and PVL gene

\section{DISCUSSION}

Antimicrobial sensitivity of Staphylococcus aureus isolates was tested for following purposes: (I) to know MRSA and MSSA (II) to find out the correlation of Ciprofloxacin sensitivity with PVL gene, as it has been considered that PVL gene ratio is high among Ciprofloxacin sensitive Staphylococcus aureus ${ }^{16}$ (III) To know frequency of MDR isolates (IV) any unusual pattern in AST. All isolates were sensitive to Vancomycin and Linezolid while $97.4 \%$ of samples were resistant to Penicillin. In current research, among 384 samples, 68.5\% were MRSA and $31.5 \%$ were MSSA. Among MRSA 50.6\% have PVL gene while in MSSA $43.8 \%$ have PVL gene. Suberna Roy et al. from India have reported $85.1 \%$ PVL gene in MRSA and $48.8 \%$ in MSSA which indicated a higher prevalence of PVL gene than our findings. ${ }^{14}$ Another study conducted in Pakistan in 2016 reported 44\% MRSA and 55\% MSSA while PVL gene frequency in MRSA was $31 \%$ and in MSSA it was $18 \%{ }^{15}$ indicated a lower prevalence of PVL gene than our findings. So, current research work indicates that the frequency of both MRSA and PVL is increasing in our setup with the passage of time. This may be due to unnecessary and excessive use of antibiotics in our setup that is making isolates more antibiotic resistant and causing poor infection control and selection of resistant isolates in the community.

It has been assessed that PVL gene frequency is usually high in Ciprofloxacin sensitive Staphylococcus aureus. ${ }^{16}$ In 2008, guidelines were published in the UK regarding the treatment of PVL positive Staphylococcus aureus infections that emphasized that only Ciprofloxacin sensitive cases should be sent to the laboratory for evaluation of PVL gene. ${ }^{17}$ We found high percentage of PVL gene 
in Ciprofloxacin sensitive Staphylococcus aureus but the difference of percentage was not so high and it was also not statistically proved. In current investigation, Ciprofloxacin resistance in Staphylococcus aureus is $72 \%$ while it had been reported as low as less than 3\% from England and Wales. ${ }^{6}$ These results reflect that prevalence of Ciprofloxacin resistance and PVL gene varies greatly between geographical locations and populations. Our investigation shows that more than half of Staphylococcus aureus were resistant to Erythromycin and PVL gene frequency was high in Erythromycin resistant Staphylococcus aureus. These results are in accordance with the results in Nepal. ${ }^{5}$ Current results show that $38 \%$ of Staphylococcus aureus were resistant to Gentamycin and frequency of PVL gene was high in Gentamycin sensitive cases. Gentamycin resistance in Staphylococcus aureus was reported 20\% in research from England. Moreover, 37\% of Staphylococcus aureus were resistant to Fusidic acid while PVL gene frequency was high in Fusidic acid sensitive. Fusidic acid resistance in Staphylococcus aureus was reported 33\% in research from England and Wales in 2005. ${ }^{6}$ Due to sensitivity testing of isolates, it was easy to find out MDR and non-MDR frequency in these isolates.PVL gene frequency was high in MDR. In current study, 75\% Staphylococcus aureus were MDR and 25\% were non-MDR while a study from South India reports $91 \%$ MDR isolates. ${ }^{18}$

\section{CONCLUSION}

Almost half of Staphylococcus aureus isolates were found PVL positive. They were mostly multidrug resistant. The PVL positive Staphylococcus aureus isolates showed high resistance against antibiotics than PVL negative isolates.

\section{Acknowledgement:}

I am grateful to all the staff of Microbiology Department, Shaikh Zayed Hospital Lahore specially our supervisor Prof. Mateen Izhar for his guidance from topic selection to thesis compilation and for funding in this research. All samples were collected and processed in Microbiology Laboratory Shaikh Zayed Hospital Lahore.

\section{REFERENCES}

1. Aboud SA, El-yamani A, Hussain MA, Ahmed A. Prevalence and antibiotics sensitivity of Staphylococcus aureus skin infection in children in Khartoum, Sudan. Curr Res Micro. Biotechnol. 2015; 3(4):690-3.
2. Boyle-Vavra S, Daum RS. Community-acquired methicillin-resistant Staphylococcus aureus: the role of Panton-Valentine leukocidin. Laboratory investigation. 2007 Jan; 87(1):3.

3. McNeil JC, Hulten KG, Kaplan SL, Mason EO. Decreased susceptibilities to Retapamulin, Mupirocin, and Chlorhexidine among Staphylococcus aureus isolates causing skin and soft tissue infections in otherwise healthy children. Antimicrobial agents and chemotherapy. 2014 May 1; 58(5):2878-83.

4. Sina H, Ahoyo TA, Moussaoui W, Keller D, Bankolé HS, Barogui Y, Stienstra Y, Kotchoni SO, Prévost G, Baba-Moussa L. Variability of antibiotic susceptibility and toxin production of Staphylococcus aureus strains isolated from skin, soft tissue, and bone related infections. BMC microbiology. 2013 Aug 8; 13(1):188.

5. Bhatta DR, Cavaco LM, Nath G, Kumar K, Gaur A, Gokhale S, Bhatta DR. Association of Panton Valentine Leukocidin (PVL) genes with methicillin resistant Staphylococcus aureus (MRSA) in Western Nepal: a matter of concern for community infections (a hospital based prospective study). BMC infectious diseases. 2016 May 15; 16(1):199.

6. Holmes A, Ganner M, McGuane S, Pitt TL, Cookson BD, Kearns AM. Staphylococcus aureus isolates carrying Panton-Valentine leucocidin genes in England and Wales: frequency, characterization, and association with clinical disease. Journal of clinical microbiology. 2005 May 1; 43(5):2384-90.

7. Herold BC, Immergluck LC, Maranan MC, Lauderdale DS, Gaskin RE, Boyle-Vavra S, Leitch CD, Daum RS. Community-acquired methicillin-resistant Staphylococcus aureus in children with no identified predisposing risk. Jama. 1998 Feb 25; 279(8):593-8.

8. Vandenesch F, Naimi T, Enright MC, Lina G, Nimmo GR, Heffernan H, Liassine N, Bes M, Greenland T, Reverdy ME, Etienne J. Community-acquired methicillin-resistant Staphylococcus aureus carrying PantonValentine leukocidin genes: worldwide emergence. Emerging infectious diseases. 2003 Aug;9(8):978.

9. Moran GJ, Krishnadasan A, Gorwitz RJ, Fosheim GE, McDougal LK, Carey RB, Talan DA. Methicillin-resistant S. aureus infections among patients in the emergency department. New England Journal of Medicine. 2006 Aug 17; 355(7):666-74.

10. Supersac G, Prévost G, Piémont Y Sequencing of leucocidin R from Staphylococcus aureus 
P83 suggests that staphylococcal leucocidins and gamma-hemolysin are members of a single, two-component family of toxin, Infect Immun, 1993, vol. 61 (pg. 580-7)

11. Prévost G, Supersac G, Colin D, et al. FreerJ, Aitken R, Alouf JE, et al. The new family of leucotoxins from Staphylococcus aureus: structural and biological properties, Zentralbl Bakteriol Suppl 24, 1994 Stuttgart Gustav Fischer Verlag (pg. 284-93).

12. Finck-Barbançon V, Duportail G, Meunier O, Colin DA. Pore formation by two-component leukocidin from Staphylococcus aureus within the membrane of human polymorphonuclear leukocytes, Biochem Biophys Acta, 1993, vol. 1182 (pg. 275-82).

13. Shrestha B, Singh W, Raj VS, Pokhrel BM, Mohapatra TM. High prevalence of PantonValentine leukocidin (PVL) genes in nosocomial-acquired Staphylococcus aureus isolated from tertiary care hospitals in Nepal. BioMed Research International. 2014.

14. Kaur H, Purwar S, Saini A, Kaur H, Karadesai SG, Kholkute SD, Roy S. Status of methicillinresistant Staphylococcus aureus infections and evaluation of PVL producing strains in Belgaum, South India. JKIMSU. 2012 Jul 1; 1(2):43-51.

15. Madzgalla S, Syed MA, Khan MA, Rehman SS, Müller E, Reissig A, Ehricht R, Monecke S. Molecular characterization of Staphylococcus aureus isolates causing skin and soft tissue infections in patients from Malakand, Pakistan. European Journal of Clinical Microbiology \& Infectious Diseases. 2016 Sep 1; 35(9):1541-7.

16. Ellington MJ, Perry C, Ganner M, Warner M, Smith IM, Hill RL, Shallcross L, Sabersheikh S, Holmes A, Cookson BD, Kearns AM. Clinical and molecular epidemiology of ciprofloxacinsusceptible MRSA encoding PVL in England and Wales. European journal of clinical microbiology \& infectious diseases. 2009 Sep 1; 28(9):1113.

17. Health Protection Agency. Guidance on the diagnosis and management of PVL-associated Staphylococcus aureus infections (PVL-SA) in England.
18. Rajan V, Schoenfelder SM, Ziebuhr W, Gopal S. Genotyping of community-associated methicillin resistant Staphylococcus aureus (CA-MRSA) in a tertiary care centre in Mysore, South India: ST2371-SCCmec IV emerges as the major clone. Infection, Genetics and Evolution. 2015 Aug 1; 34:230-5.

\section{The Authors:}

Dr. Asma Akram

Senior Demonstrator,

Department of Pathology,

Continental Medical College, Lahore.

Prof. Mateen Izhar

Head, Department of Microbiology and Virology, Shaikh Zayed Medical Complex, Lahore.

Dr. Anwaar Basheer

Associate Professor,

Department of Microbiology and Virology,

Shaikh Zayed Medical Complex, Lahore.

Dr. Mariya Ali

Senior Demonstrator,

Department of Pathology,

Continental Medical College, Lahore.

Dr. Asma Yaqoob

Senior Demonstrator,

Department of Pathology,

Fatima Memorial Medical \& Dental College,

Lahore.

Dr. Asim Saifullah

Senior Registrar,

Department of Pediatric Orthopedic Surgery,

Children Hospital, Lahore.

\section{Corresponding Author}

Dr. Asma Akram

Senior Demonstrator,

Department of Pathology,

Continental Medical College, Lahore.

E-mail: asmaasim26@gmail.com 